\title{
ADAPTATIONS OF INDIGENOUS BACTERIA TO FUEL CONTAMINATION IN KARST AQUIFERS IN SOUTH-CENTRAL KENTUCKY
}

\author{
Tom D. Byl ${ }^{1,2 *}$, David W. Metge², Daniel T. Agymang ${ }^{2}$, Mike Bradley¹, Gregg Hileman, \\ AND RoN W. HARVEY3
}

\begin{abstract}
The karst aquifer systems in southern Kentucky can be dynamic and quick to change. Microorganisms that live in these unpredictable aquifers are constantly faced with environmental changes. Their survival depends upon adaptations to changes in water chemistry, taking advantage of positive stimuli and avoiding negative environmental conditions. The U.S. Geological Survey conducted a study in 2001 to determine the capability of bacteria to adapt in two distinct regions of water quality in a karst aquifer, an area of clean, oxygenated groundwater and an area where the groundwater was oxygen depleted and contaminated by jet fuel. Water samples containing bacteria were collected from one clean well and two jet fuel contaminated wells in a conduit-dominated karst aquifer. Bacterial concentrations, enumerated through direct count, ranged from 500,000 to 2.7 million bacteria per $\mathrm{mL}$ in the clean portion of the aquifer, and 200,000 to 3.2 million bacteria per $\mathrm{mL}$ in the contaminated portion of the aquifer over a twelve month period. Bacteria from the clean well ranged in size from 0.2 to $2.5 \mu \mathrm{m}$, whereas bacteria from one fuel-contaminated well were generally larger, ranging in size from 0.2 to $3.9 \mu \mathrm{m}$. Also, bacteria collected from the clean well had a higher density and, consequently, were more inclined to sink than bacteria collected from contaminated wells. Bacteria collected from the clean portion of the karst aquifer were predominantly $(\sim 95 \%)$ Gram-negative and more likely to have flagella present than bacteria collected from the contaminated wells, which included a substantial fraction $(\sim 30 \%)$ of Gram-positive varieties. The ability of the bacteria from the clean portion of the karst aquifer to biodegrade benzene and toluene was studied under aerobic and anaerobic conditions in laboratory microcosms. The rate of fuel biodegradation in laboratory studies was approximately 50 times faster under aerobic conditions as compared to anaerobic, sulfur-reducing conditions. The optimum $\mathrm{pH}$ for fuel biodegradation ranged from 6 to 7. These findings suggest that bacteria have adapted to water-saturated karst systems with a variety of active and passive transport mechanisms.
\end{abstract}

\section{INTRODUCTION}

Approximately $40 \%$ of the United States east of the Mississippi River is considered karst terrain (Quinlan, 1989). Over $55 \%$ of Tennessee and Kentucky is underlain by carbonate rocks and exhibits classic karst features such as sinkholes, disappearing streams, and cave systems (Wolfe et al., 1997; Florea et al., 2002). The karst conduit systems provide habitat to a diverse fauna (Schneider and Culver, 2004) and can be an important source of water for humans (Hutson, 1995) and the ecosystem. Despite the common occurrence and importance of karst aquifers, very little is reported in the scientific literature about the adaptations of indigenous bacteria found in water-saturated karst conduits (Byl et al., 2002). Karst aquifers provide distinct hydrologic and chemical environments compared to unconsolidated sandy aquifers. For example, karst conduits typically offer much smaller surface areas for biofilm development per volume of water relative to granular aquifers. It is therefore reasonable to assume that there are different adaptations and distributions in karst microbial communities as compared to those reported for sandy aquifers (Haack et al., 2012; Harvey et al., 1984; Harvey et al., 1997; Kölbel-Boelke et al., 1988; Barton and Northup, 2007).

There are different types of karst systems throughout the United States and the world (White, 2002). The karst aquifers of north-middle Tennessee and southern Kentucky may trap large volumes of water in fractures along bedding planes and other features isolated from active groundwater flowpaths (Wolfe et al., 1997). In essence, there are dissolution openings with actively flowing waters, as well as stagnant water-filled openings with substantially longer

\footnotetext{
* Corresponding Author: tdbyl@usgs.gov

${ }^{1}$ U.S. Geological Survey, Nashville, TN, 37211

${ }^{2}$ Tennessee State University, Civil \& Environmental Engineering Dept., Nashville, TN, 37209

${ }^{3}$ U.S. Geological Survey, Boulder, CO, 80303
} 
residence times. In these stagnant areas isolated from the major groundwater flowpaths, the bacteria and water may reside long enough to have a substantial effect on the geochemistry in that part of the aquifer (Byl and Williams, 2000; Byl et al., 2001). The geochemistry in these conduits can range from aerobic to anaerobic and is affected by recharge events.

The potential for contamination to enter and spread rapidly through a karst-conduit system is high, but the response of indigenous bacteria to dissolved contaminants in these water-filled conduit systems is poorly understood. Barton (2006) mentions a bacterium identified in Carlsbad Caverns, New Mexico, that can degrade complex aromatic compounds like benzothiazole and benzenesulfonic acid. Other bacteria, collected in Lechuguilla Cave, New Mexico, possess the ability to fix nitrogen, metabolize complex aromatic compounds, turn over lipids, and scavenge scarce nutrients (Barton and Jurado, 2007). Northrup and Lavoie (2001) conducted a study that showed bacteria thrive in karst systems under a variety of redox conditions, thus demonstrating that they have adapted to using a variety of terminal electron acceptors. In a previous study in south-middle Tennessee, Byl and Williams (2000) demonstrated that bacteria in a karst aquifer can biodegrade trichloroethylene by reductive dechlorination. It is clear that karst bacteria have adapted to biodegrade a variety of compounds under a broad range of geochemical conditions.

The karst aquifers of southern Kentucky are known for being hydrologically responsive to rain events (Ryan and Meimen, 1996; Vesper and White, 2006). Consequently, it would be expected that some of the evolutionary adaptations within the native microbial communities would facilitate coping with sudden changes. In 2001, the U.S. Geological Survey conducted a study to examine adaptations of the indigenous bacteria found in water-filled karst conduit systems by monitoring bacterial response to jet fuel contamination and $\mathrm{pH}$ changes. The scope of the study included the collection of bacterial communities from clean and fuel contaminated portions of the same aquifer and the comparison of their population sizes, buoyant densities, Gram types, and average cell sizes. This paper examines adaptations, size and quantity of bacteria, and rates of fuel biodegradation under both aerobic and anaerobic conditions.

\section{Study Area Description}

Three wells located near an airfield in south-central Kentucky were selected for this study because they represented two distinct areas of water quality in the karst aquifer: an area containing uncontaminated groundwater and an area where the groundwater had been contaminated by jet fuel (Fig. 1a and 1b). Two fuel-contaminated bedrock wells (MW-1 and MW-2) were located downgradient from an uncontaminated bedrock monitoring well (MW-3) located approximately 100 feet upgradient from
MW-1 and 150 feet upgradient from MW-2 (Fig. 1a). Quarterly sampling had detected no petroleum hydrocarbons in the clean well during the previous 10 years (Dames and Moore, Inc., 2001). The airfield had several reported fuel leaks over several decades of intensive use. Wells drilled and screened in the bedrock during the 1980s confirmed the presence of dissolved fuels in specific areas of the karst aquifer (Ewers et al., 1992). The pH fluctuated between 6.4 and 7.8 in the clean well and contaminated well MW-2. The wells were cased with 4-inch PVC pipe and screened in the upper bedrock at 120 to 136 feet below ground surface (Fig. 1b).

\section{Methods And Materials}

Water samples for this study were collected in May, June, September, and December of 2001 from wells MW-3 and MW-1. Well MW-2 was added after a sudden increase in $\mathrm{pH}$ was observed in $\mathrm{MW}-1$. The $\mathrm{pH}$ change from approximately 7 to 12 was due to the over-drilling of a 31-m (100-ft) deep well filled with ash material that was initially designed to be used as an anode to reduce fuel-pipe corrosion around the airfield (Fig. 1a). The anode well was converted to an extraction well, but in the process of overdrilling and grouting the new well, the $\mathrm{pH}$ of the surrounding aquifer jumped to 12 . This extreme increase in $\mathrm{pH}$ provided a unique opportunity to observe how the bacteria in the pH-altered part of the aquifer would respond to a sudden and prolonged change from neutral to strongly alkaline conditions. The $\mathrm{pH}$ in the alternate wells

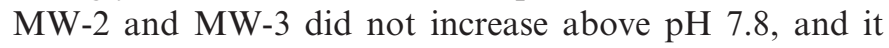
appeared to be unaffected by the $\mathrm{pH}$-altering activities close to well MW-1.

\section{Collection of Groundwater and Bacteria}

Water samples were collected by lowering the intake of a cleaned, decontaminated Grundfos jet pump in the wells to specified depths equivalent to the conduit openings (Any use of trade, firm, or product names is for descriptive purposes only and does not imply endorsement by the U.S. Government). For example, in well MW-3, the pump intake was lowered to $40 \mathrm{~m}$ below the top of casing because geophysical logging indicated there was a $5 \mathrm{~cm}$ water-filled conduit opening at this level. The water was pumped at a rate of 1.5 to $3 \mathrm{~L} \mathrm{~min}^{-1}$ until specific conductance and temperature remained steady for fifteen minutes or more. The purging generally took thirty to forty minutes. Water levels in the well did not fluctuate during pumping, indicating that the water being collected was primarily drawn from the bedrock openings and not from the stagnant well-casing water. The groundwater collected ranged from clear to slightly turbid, with a steady temperature of $14.7{ }^{\circ} \mathrm{C}$. The specific conductance ranged from 340 to $440 \mu \mathrm{S} \mathrm{cm}^{-1}$ in the clean well and 340 to $600 \mu \mathrm{S} \mathrm{cm} \mathrm{cm}^{-1}$ in the contaminated wells, depending on recent rain events. 


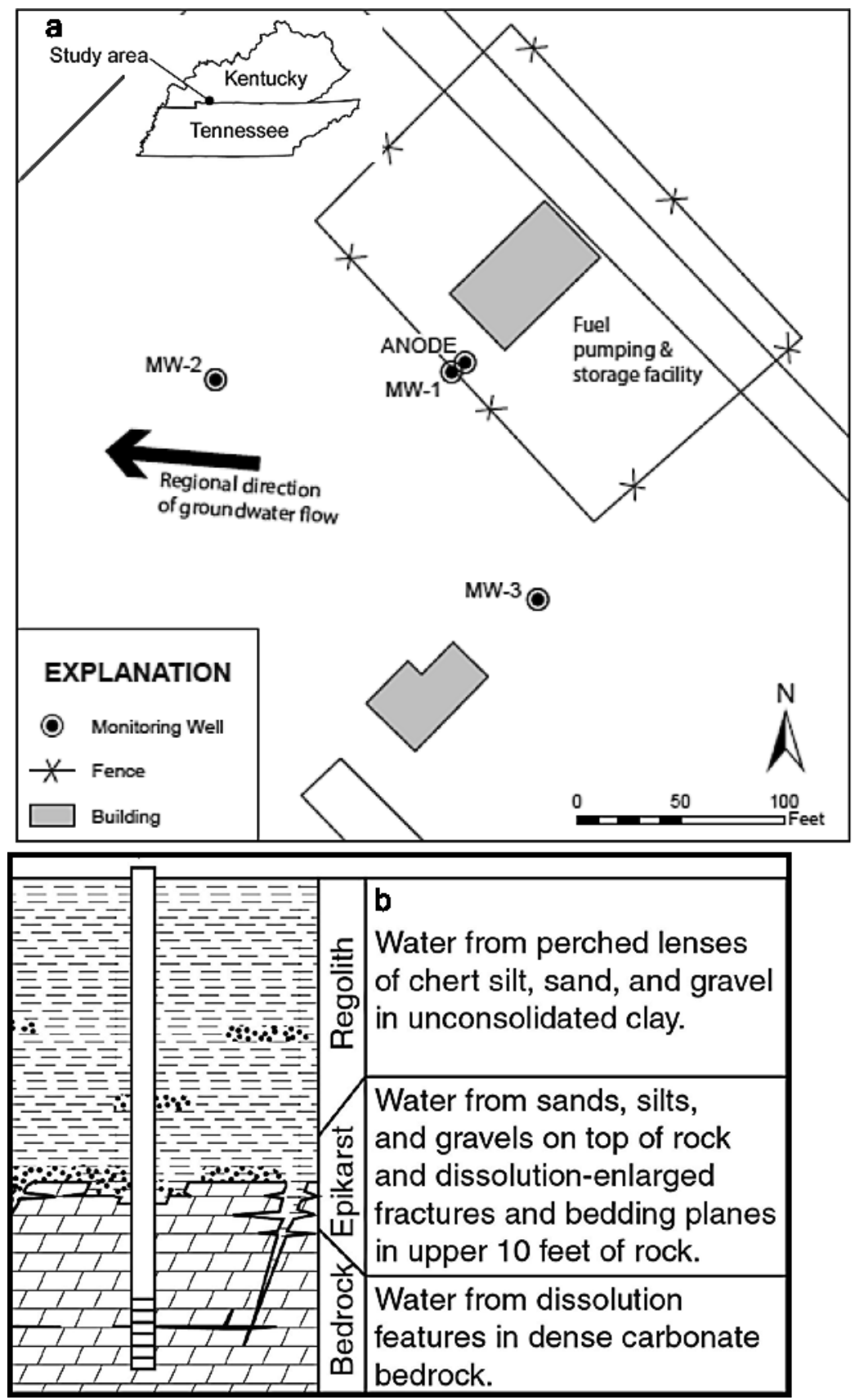

Figure 1. Map of site investigation area, plan view (a), and a conceptual cross section of the wells used in the study (b). Well MW-2 was polluted with fuel, and well MW-3 was clean. The water in well MW-1 changed during the study due to the drilling of nearby well ANODE.

The jet pump used to collect water samples was relatively new and had a Teflon hose. Between uses, the pump was cleaned with a weak $0.3 \%$ bleach solution and rinsed with heat-sterilized distilled water to remove hypochlorite residue. Quality control tests conducted on the decontaminated pump system found less than 10 bacteria per $\mathrm{L}$ water, indicating there was insignificant microbial cross-contamination due to the pump system. The groundwater samples for geochemical and bacterial analyses were collected in clean, sterile, 1 L brown glass bottles. Samples for analysis of volatile organic compounds (VOCs) were collected in clean, $40 \mathrm{~mL}$ brown glass bottles. All bottles were over-filled to avoid headspace and prevent sample volatilization and sealed with a sterile cap. The bottles were placed on ice and transferred to the laboratory at Tennessee State University in Nashville, Tennessee, for microbial, VOC, and geochemical analysis. VOC analysis was done on a Syntex gas chromatograph equipped with a 
purge-and-trap system, $30 \mathrm{~m}$ by $0.32 \mathrm{~mm}, 1.8 \mu \mathrm{m}$ silica-film capillary column, argon carrying gas, and micro-argon ionization detector. The lower detection limit for toluene and benzene on this GC was 0.5 microgram per liter $\left(\mu \mathrm{g} \mathrm{L}^{-1}\right)$. Every fourth sample was either a duplicate sample or a standard of known toluene concentration. A complete calibration curve of benzene, toluene, ethylbenzene, and xylenes was run prior to and after the microcosm samples. Benzene and toluene were the only monoaromatic ring compounds identified in the water. Additional unidentified peaks were present in the samples. Results of the VOC analysis were organized and graphed on a spreadsheet. Bacterial samples that were analyzed for buoyant density, size, and microscope direct counts were packed on ice and shipped overnight to the USGS laboratory in Boulder, Colorado.

\section{Bacterial Quantification, Flagella, and \\ Average Size}

Two methods were used to quantify the bacteria, a direct count on the microscope and a liquid culturing method. The direct count method counts all bacteria, even those that are dormant, whereas the liquid culturing method provides a population estimate based on the bacteria that are actively dividing and growing. Additional microscopic examination was done to assess the presence or absence of flagella and the Gram-staining characteristics of the bacteria. Traditional Gram staining was conducted, and the result was viewed under a bright-field microscope (Beveridge, 2001). Bacteria flagella staining and viewing was done as described in Grossart et al. (2000).

Direct count and size frequency analyses of free-living bacteria were done using a Nikon Optiphot II epifluorescence microscope and an ITC image processor connected to a personal computer, a Dage SIT66 black and white camera, and a Sony black and white monitor. The image system was optimized to analyze and calculate length, width, area, and perimeter of fluorescent-stained (acridine orange) bacteria in samples previously analyzed for bacterial abundance. Measurements from the image system were standardized using fluorescent-stained $0.45,0.95$, and $1.07 \mu \mathrm{m}$ microspheres in order to convert pixel measurements to micrometers. All analyses were performed at microscope magnifications of 788 to 1260 .

Biological Active Reaction Tests (BART) were conducted to estimate the culturable heterotrophic aerobic bacteria in the groundwater. The BART assays use selective media to grow particular groundwater bacterial types (DBI, 2004). Twenty $\mathrm{mL}$ of groundwater were transferred from a sample bottle, having been vigorously shaken to re-suspend the bacteria, into the BART vials, sealed, and incubated in the dark at $22{ }^{\circ} \mathrm{C}$ for 7 days. The vials were checked every 24 hours for visible signs of bacteria growth, which was evident by dye-color changes and cloudiness, as described by Cullimore (2008, chapter 9). Growth patterns were recorded and compared to the growth charts to establish an estimate of the culturable bacterial concentration in the groundwater. Results were reported as bacteria per $\mathrm{mL}$.

\section{Buoyant-Density and Density-Gradient \\ DETERMINATIONS}

Buoyant-density determinations were performed using the method described by Harvey et al. (1997). Approximately $2 \mathrm{~L}$ of uncontaminated groundwater or $1 \mathrm{~L}$ of contaminated groundwater was filtered through $47 \mathrm{~mm}$ (diameter), $0.2 \mu \mathrm{m}$ (pore size) polycarbonate membrane filters at -0.3 atmosphere transmembrane pressure. Bacteria retained by the filters were gently washed with sterile saline solution ( $2 \mathrm{mM} \mathrm{NaCl}, \mathrm{pH}$ 6.8) and resuspended in sterile $0.15 \mathrm{M} \mathrm{NaCl}$ to provide a cloudy suspension consisting of 1 to 400 cells per mL. Microscopic examination revealed that the vast majority of bacteria were single and not attached to particles. Few nonbacterial colloids were observed. Density gradients were created within transparent, $50-\mathrm{mL}$ Oak Ridge or $10 \mathrm{~mL}$ polycarbonate centrifuge tubes using Percoll I solution (1.131 $\mathrm{g} \mathrm{cm}^{-3}$, Sigma Chemical Company, St. Louis, Missouri), a colloidal silica suspension, diluted with $0.15 \mathrm{M}$ $\mathrm{NaCl}$. The tubes were then spun for 30 minutes at 15,000 G in a Sorvall RC-5B refrigerated centrifuge. The resulting gradient formed symmetrically on either side of the starting density of $1.100 \mathrm{~g} \mathrm{~cm}^{-3}$. Brightly colored density marker beads obtained from Sigma Chemical Company were used to indicate specific buoyant-density values along the longitudinal axis of the tubes. Aliquots $(2.5 \mathrm{~mL})$ of the bacterial suspensions were carefully layered on the top of the pre-formed gradients. Gradient tubes containing the bacteria were spun at 15,000 $\mathrm{G}$ for 1 hour. The equilibrium positions of the bacterial populations were observed as distinct translucent bands. The buoyant densities of the populations were indicated by the position of the bacterial bands relative to those of the marker beads. The band thickness (in $\mathrm{mm}$ ) provided a semi-quantitative measure of the microbial population corresponding to a particular buoyant density. The total thickness of the bands equals 100 percent, and each band represents a subset or percentage of that total band thickness.

\section{Batch Microcosms for Biodegradation Studies}

The rate at which the cultured bacteria degraded fuels under aerobic or anaerobic conditions and under different $\mathrm{pH}$ conditions was the subject of microcosm studies. Stagnant batch microcosms were established using raw, unfiltered water collected from either well MW-3 or well MW-2. Water from well MW-3 was used to set up the aerobic microcosms because the waters consistently had dissolved oxygen readings of $3 \mathrm{mg} \mathrm{L}^{-1}$ or higher. Anaerobic microcosms were established using water from well MW-2, which consistently had less than $0.5 \mathrm{mg} \mathrm{L}^{-1}$ dissolved oxygen. The microcosms consisted of $300-\mathrm{mL}$ brown, biological-oxygen-demand (BOD) glass bottles 


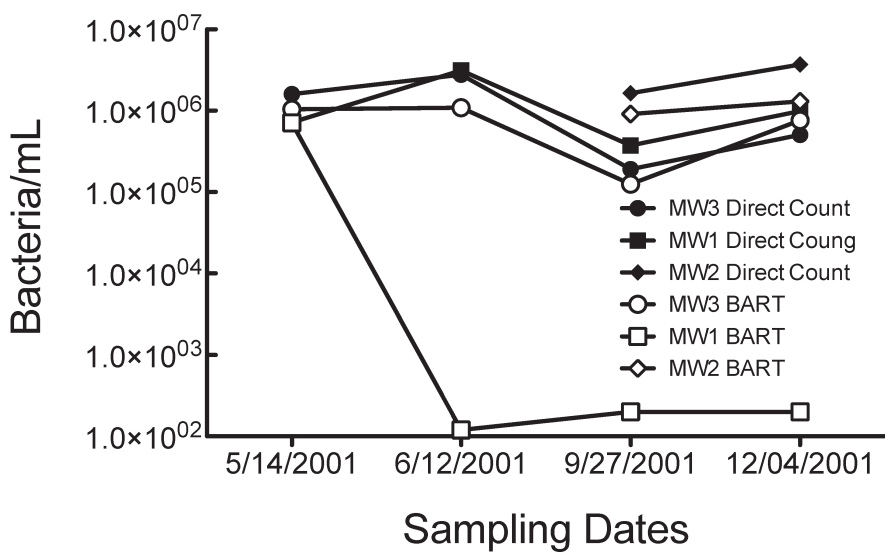

Figure 2. Bacteria quantified in waters collected from three wells intersecting a water-filled conduit in south-central Kentucky, as measured by microscope counting and by BART analyses. The pH of well MW-3 changed following May 2001.

incubated at $25{ }^{\circ} \mathrm{C}$, which is approximately 10 degrees warmer than natural conditions in the conduit. Microcosms were sampled at five different harvest times with three replicates per harvest, aerobic and anaerobic conditions, for a total of thirty microcosms. Aerobic microcosms were harvested on days $0,1,3,5$, and 7. Anaerobic microcosms were harvested on days $0,2,5,7$, and 10 . The dissolved oxygen levels were measured in each microcosm upon harvest to confirm aerobic and anaerobic conditions using YSI-5100 BOD meters. The data from the fifth harvest for the aerobic microcosms were not used because the oxygen had been consumed, and the microcosms had gone anaerobic. Additional sterile and pH-altered microcosms were established for comparison. The $\mathrm{pH}$ was adjusted from 6.85 with sodium hydroxide or hydrochloric acid to achieve $\mathrm{pH}$ of $2,5,7,9$, and 12 .

\section{RESULTS}

\section{Bacterial Quantification, Flagella, Size, and BuOYANT DENSITY}

The microbial population in the three sampled wells ranged from 200,000 to almost 4,000,000 bacteria per $\mathrm{mL}$ (Fig. 2). Population growth measured by direct counts and BART assays had a similar pattern with the exception of contaminated well MW-1. As mentioned earlier, the $\mathrm{pH}$ in MW-1 increased from 7 to 12 as a result of nearby drilling activities in late May, between the first and second sampling events. Alkaline conditions will often hamper microbial metabolism and promote detachment of bacteria from aquifer surfaces (Harvey et al., 2010). The sharp increase in $\mathrm{pH}$ at $\mathrm{MW}-1$ resulted in an increase in bacteria using the direct-count method in the June 2001 sample, but a $99.99 \%$ drop in viable bacteria determined by the BART method. Enumerating environmental bacteria using tradi- tional culturing techniques, such as agar media plates, can result in questionable bacterial counts due to a low cultivatable percentage (Barton et al., 2004). But the BART tests, which are also growth-based assays, did provide important information concerning the viability of the bacteria. Using the direct count method alone would have provided a false sense that this part of the karst aquifer had 3-million bacteria per $\mathrm{mL}$ in June, when the viable bacteria count really dropped from $\sim 1$ million to $\sim 100$ bacteria per mL.

With the exception of the pH-shocked well (MW-1), there was generally good agreement between the direct counts and the BART estimates. There was a rise and fall in bacteria numbers during the sampling period. Unfortunately, there were insufficient data to conclude whether population flux was due to seasonal patterns or recent weather events. It is clear, however, that bacterial concentrations in the karst conduit water can fluctuate an order of magnitude over several months. The BART method generally provided lower population estimates than the direct count method, indicating that some bacteria types did not grow, and were not measured. However, the BART bacterial estimates were closer to the direct counts than traditional heterotrophic plate counts, which were in the hundreds to thousands of colony forming units per $\mathrm{mL}$ (data not shown). The BART assay is different from conventional plate-count methods in several aspects. The BART system allows the water-borne bacteria to remain free-living in the water or to attach to a surface and maintain symbiotic associations. The BART vials provide nutrient and oxygen gradients in the test waters, which offer different types of bacteria their optimal habitat zones.

Microbial samples were Gram stained and viewed using bright-field microscopy. Gram stain has traditionally been used by microbiologists to help identify bacteria based on cell-wall make-up. Aquifer bacteria can alter their cell-wall chemistry under different environmental conditions (Harvey et al., 2011), thereby affecting their ability to hold the Gram stain (Beveridge, 2000). Thus, the objective of this Gram staining effort was to provide information about relative differences in the average composition of the cell envelope in clean versus contaminated conduits. Bacteria collected from the clean well, MW-3, were approximately 95\% Gram-negative rods, whereas bacteria collected from MW-1 and MW-2 were 68\% Gram-negative. The increase in Gram-positive bacteria in the presence of fuel has been observed by other investigators (Fahy et al., 2008; Ramos et al., 2002). They found Gram-positive bacteria were better competitors than Gram-negative organisms at high benzene concentrations, which suggests that some Grampositive bacteria are tolerant of high fuel concentrations and can play a role in the natural attenuation of fuel. Segura et al. (1999) list three mechanisms used by Grampositive bacteria tolerant to aromatic hydrocarbons, metabolizing the toxic hydrocarbons, which can contribute to their transformation into non-toxic compounds, rigid- 


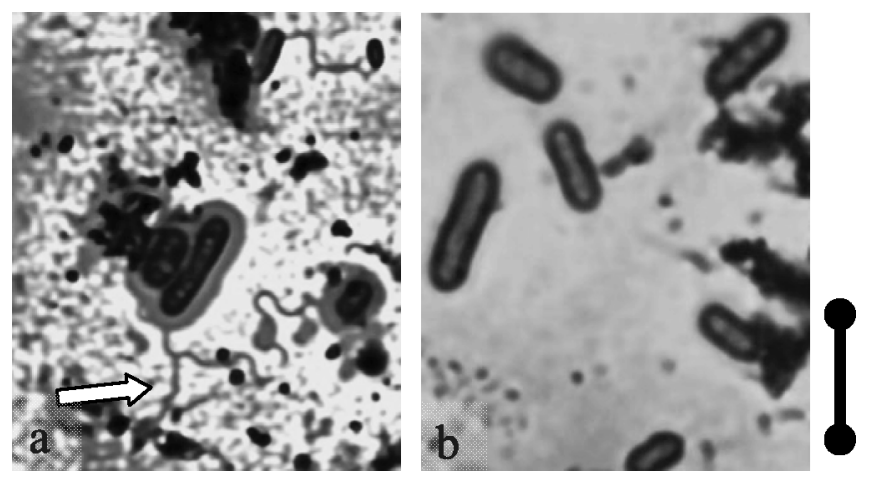

Figure 3. Rod-shaped bacteria from clean well MW-3 with polar flagella (arrow) (a), and rod-shaped bacteria from contaminated well MW-1 or MW-2 (b). Original magnification 1000×; line is $1 \mu \mathrm{m}$ long.

ifying the cell membrane by altering the composition of phospholipids, and secreting the toxic compound in an energy-dependent process.

Groundwater bacteria have been known to use different methods of locomotion. Groundwater bacteria may use directed locomotion in the presence of chemical gradients (chemotaxis) to actively pursue energy sources, thus facilitating biodegradation (Ford and Harvey, 2007). Many aquatic bacteria propel themselves using flagella (Harschey, 2003), glide by one of several methods (McBride, 2001), or modify their buoyant density and float with the groundwater (Harvey et al., 1997). The use of flagella for locomotion is energy intensive and may be limited in anaerobic environments, where rapid expenditure of energy is costly to the organism. Alternatively, modifying the organism's buoyant density, thereby allowing the bacterium to float in the waterfilled conduit openings, would be a low-energy method of locomotion. This study took a simple look at bacteria flagella and buoyancy mechanisms collected from the clean and fuel-contaminated parts of the aquifer. Gliding mechanisms were not part of this study.

Flagella are difficult to observe because they are small and bacteria have developed mechanisms to rapidly drop their flagella when environmental conditions change (Ford and Harvey, 2007; Harschey, 2003). Nonetheless, we observed a reasonable number of flagella attached to bacteria collected from clean well MW-3 (Fig. 3a). Detached flagella were also observed. By comparison, there were no flagella observed, attached or detached, to the bacteria collected from fuel-contaminated wells (Fig. 3b). These results were not quantitative, but they do suggest that a discernable fraction of the bacteria in MW-3 use flagella to move in the water column. Alternatively, these findings suggest that flagella are not a common mode of motility in the fuel-contaminated part of the aquifer likely because of the anaerobic environment, which is not conducive to the oxygen-dependent phosphorylation energy pathway.
Bacteria living in water from wells $\mathrm{MW}-1$ or $\mathrm{MW}-2$ appear to avoid motility mechanisms that require oxygendependent respiration because the aquifer was dissolvedoxygen poor (less than $1 \mathrm{mg} \mathrm{L}^{-1}$ throughout the year-long study). The part of the aquifer intersected by well MW-3 had dissolved-oxygen levels ranging from 3 to $8 \mathrm{mg} \mathrm{L}^{-1}$. It is reasonable to assume the bacteria from oxygen-poor parts of the karst aquifer have adapted a more passive method to move about in their environment.

An important property governing microbial mobility in groundwater environments is buoyant density, also known as specific gravity. Figure 4 depicts the buoyant-density distribution of the bacteria from each well as a relative percentage derived from the bacteria band thickness after the density-gradient certifugation. One hundred percent of the bacterial population collected from MW-1 on May 14 had a very light specific gravity of 1.02 to $1.03 \mathrm{~g} \mathrm{~cm}^{-3}$. This microbial population would be relatively buoyant and inclined to float in the water column. The construction of a well nearby in the last week of May, subsequently raising the $\mathrm{pH}$ to 12 , coincided with a shift in buoyant density. The bacteria became denser and apt to descend in the water column. The microbial population in well MW-2 had a slightly lighter buoyant density (1.02 to $\left.1.04 \mathrm{~g} \mathrm{~cm}^{-3}\right)$ compared to the bacteria collected from clean well MW-3. Bacteria collected from MW-3 had a moderate buoyant density throughout the sampling period. The data generated by this method were not suitable for statistical analysis.

The size distribution of the collected bacteria from wells MW-1 and MW-3 (Fig. 5) ranged from 0.2 to $4.0 \mu \mathrm{m}$. There was a subtle excess in length in the bacteria collected from $\mathrm{MW}-1$ prior to the $\mathrm{pH}$ shift when compared to bacteria collected from MW-3. The median length of the bacteria collected from MW-3 was $0.6 \mu \mathrm{m}$. The median bacterial length found in MW-1 was $0.8 \mu \mathrm{m}$. However, because there was a large range of bacterial sizes in the clean and contaminated wells, an analysis of variance Ftest did not find the median lengths to be significantly different.

\section{Batch Microcosms for Biodegradation Studies}

Bacteria collected from the wells in this study appear to have adaptations that permit them to swim in clean waters and float in anaerobic fuel-contaminated waters. These adaptations allow the bacteria to overcome the limited surface area for biofilm development. Because they have adapted mechanisms that enhance their abilities to live unattached to rock surfaces, there is also increased opportunity for bacteria to consume dissolved constituents such as benzene and toluene in the water column. Results from the microcosm study in the laboratory indicated that the aerobic and anaerobic biodegradation rates of benzene and toluene were pseudo-first order as exponential equations. The first-order rate constant for aerobic biodegradation (Fig. 6) was 0.64 for benzene $\left(R^{2}=0.97\right)$ and 1.03 for toluene $\left(R^{2}=0.93\right)$. Under aerobic conditions, 


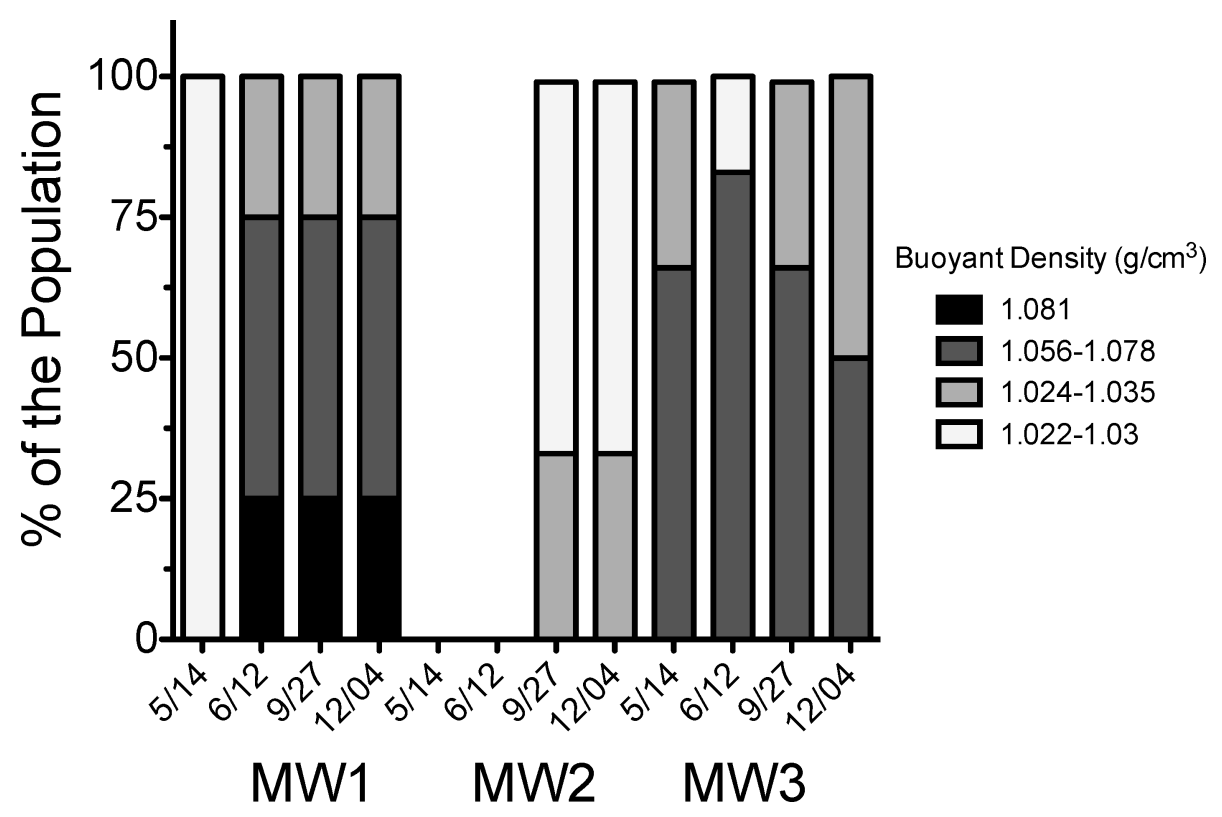

Figure 4. Buoyant densities of bacteria collected from the three karst wells shown as a percent of the total population at sample dates in 2001. MW-1, fuel-contaminated well that experienced $\mathrm{pH}$ shift to 12 prior to June; MW-2, fuel-contaminated well added to the study after June; MW-3, clean reference well.

toluene was biodegraded slightly faster than the benzene (Fig. 6), but there was not a statistically significant difference. The sterile controls lost less than $3 \%$ over the same time period.

The first-order anaerobic rate constants for degradation of benzene and toluene were essentially the same, 0.027 and 0.031 , respectively $\left(R^{2}=0.98\right.$ for both) (Fig. 7), which demonstrated that bacteria collected from the three wells in this study are capable of biodegrading fuel compounds under aerobic and anaerobic conditions. We documented both aerobic and anaerobic conditions in the bedrock aquifer at this site. Conditions in wells MW-1 and MW-2 were anaerobic, with less than $1 \mathrm{mg} \mathrm{L}^{-1}$ dissolved oxygen, which was probably due to use of oxygen as the final electron acceptor during the consumption of the dissolved fuel.

\section{Optimum pH for Fuel Biodegradation}

All enzymes, including those involved in biodegradation of fuels, have an optimum $\mathrm{pH}$. Some enzymes can function in a broad range of $\mathrm{pH}$ values. Others require a narrow and

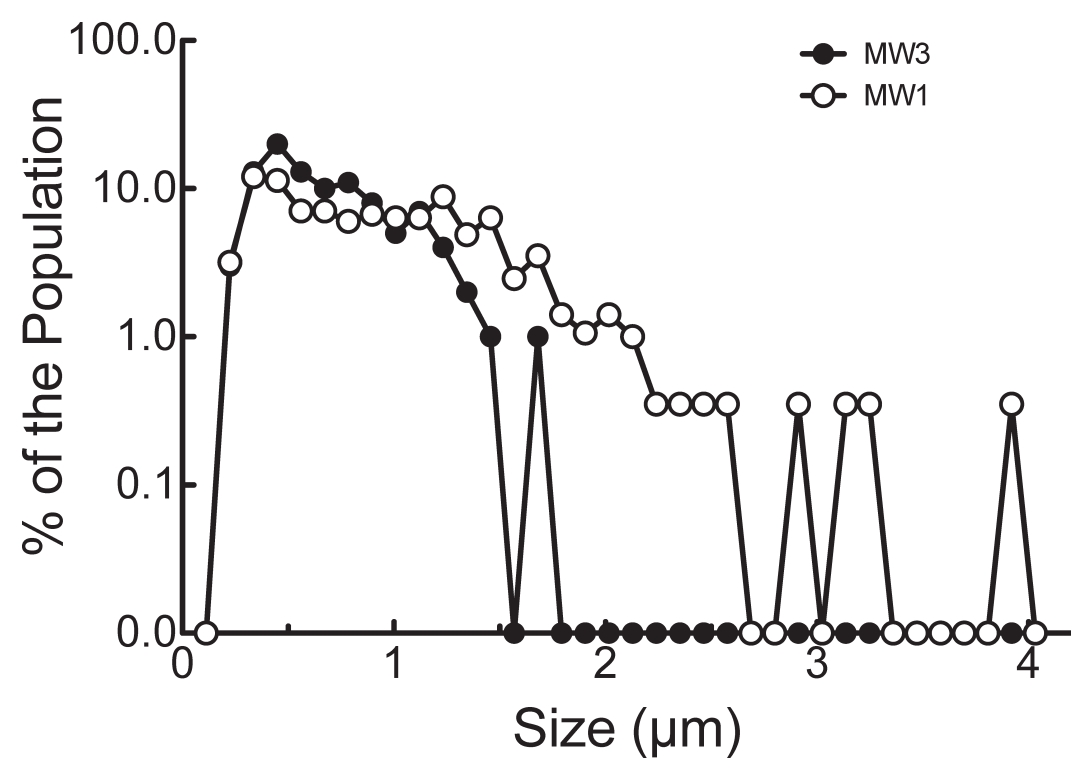

Figure 5. Bacterial size distribution for microbes collected from a clean (MW-3) and fuel-contaminated (MW-1) karst aquifer in southern Kentucky. Note logarithmic scale. The difference in the medians is not statistically significant. 


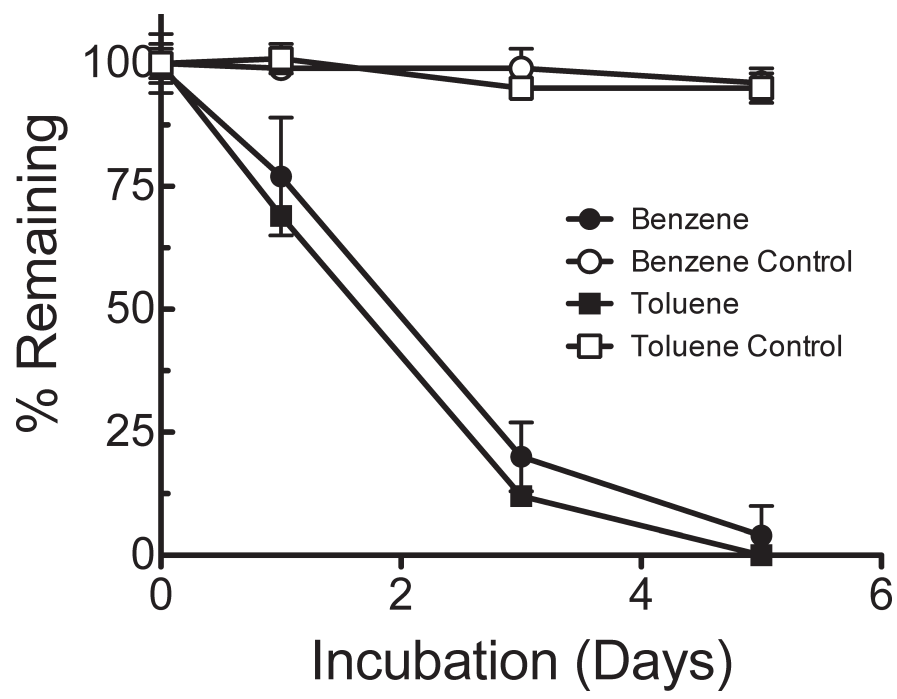

Figure 6. Aerobic biodegradation of mono-aromatic fuel compounds benzene and toluene by bacteria collected from clean well MW-3, compared to sterile control samples. Error bars are one standard deviation of three replicates.

controlled $\mathrm{pH}$ range in order to function. Aerobic samples from clean well MW-3 were treated with benzene and toluene levels of 4.8 and $15.3 \mu \mathrm{g} \mathrm{L}^{-1}$ and had $\mathrm{pH}$ adjusted to various levels as described in the methods section. Results from this microcosm study show that the microcosms with $\mathrm{pH} 2$ and 12 had no noticeable consumption of dissolved oxygen over a 12-day period; whereas the other microcosms ( $\mathrm{pH}$ values of 5 , 7, and 9) became anaerobic around day 5 (Fig. 8).

The benzene and toluene in the microcosms were measured and the data were transformed to percent

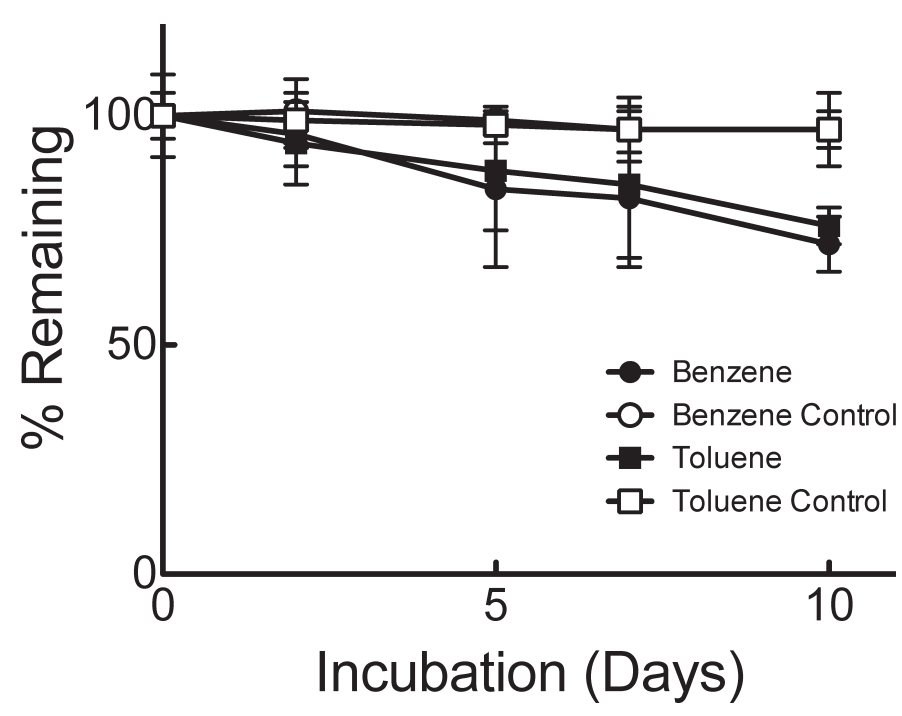

Figure 7. Anaerobic biodegradation of mono-aromatic fuel compounds benzene and toluene by bacteria collected from polluted well MW-2, compared to sterile control samples. Error bars are one standard deviation of three replicates.

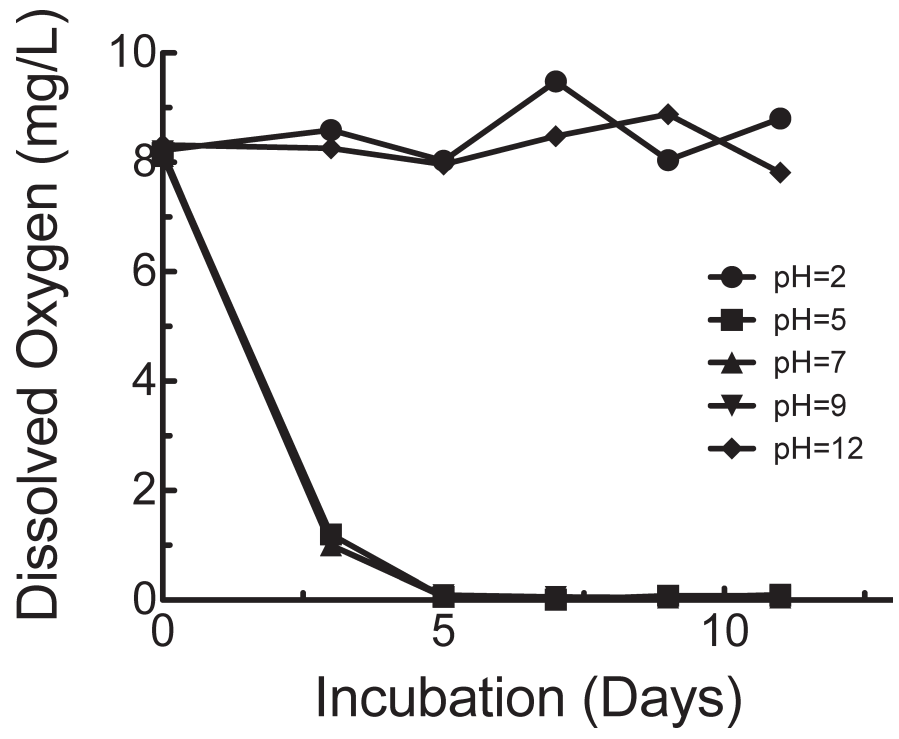

Figure 8. Dissolved oxygen levels in the static microcosms incubated over a 12-day period established using raw water from well clean well MW-3 with adjusted $\mathbf{p H}$. Samples with near-neutral pH were anaerobic by day 5 .

benzene and toluene remaining on day 5 (Fig. 9). The two microcosm treatments with $\mathrm{pH} 2$ and 12 water did not have any toluene or benzene removal over the five-day period. The greatest amount of removal was found in microcosms with neutral $\mathrm{pH}$, which indicated that the optimum $\mathrm{pH}$ for aerobic toluene or benzene biodegradation was between $\mathrm{pH} 6$ and 7 .

\section{DisCUSSION}

In spite of the austere conditions present in karst aquifers in south-central Kentucky, this study showed that these environments can harbor large numbers of bacteria, from 200,000 to $3,000,000$ bacteria per mL. Many of the bacteria in the clean, oxygenated groundwater possessed flagella for motility, whereas bacteria from the oxygendepleted, fuel-contaminated zones were less likely to have flagella and more likely to alter their buoyant density to facilitate their advective transport. A microorganism's buoyant density affects its frequency of collision with conduit surfaces because it affects the rate of settling. Buoyant density of bacteria collected in these three wells ranged from light $\left(1.02 \mathrm{~g} \mathrm{~cm}^{-3}\right)$ to dense $\left(1.08 \mathrm{~g} \mathrm{~cm}^{-3}\right)$. A similar difference in size and buoyant densities of groundwater bacteria observed in pristine versus contaminated zones of a sandy aquifer in Cape Cod, Massachusetts, resulted in an estimated 64-fold difference in their settling rates (Harvey et al., 1997). However, the relationship between bacteria shape, size, and sedimentation velocity is not fully understood, and other factors may affect sedimentation rate. The bacteria in the fuelcontaminated parts were, on average, larger than those

Journal of Cave and Karst Studies, August 2014•111 


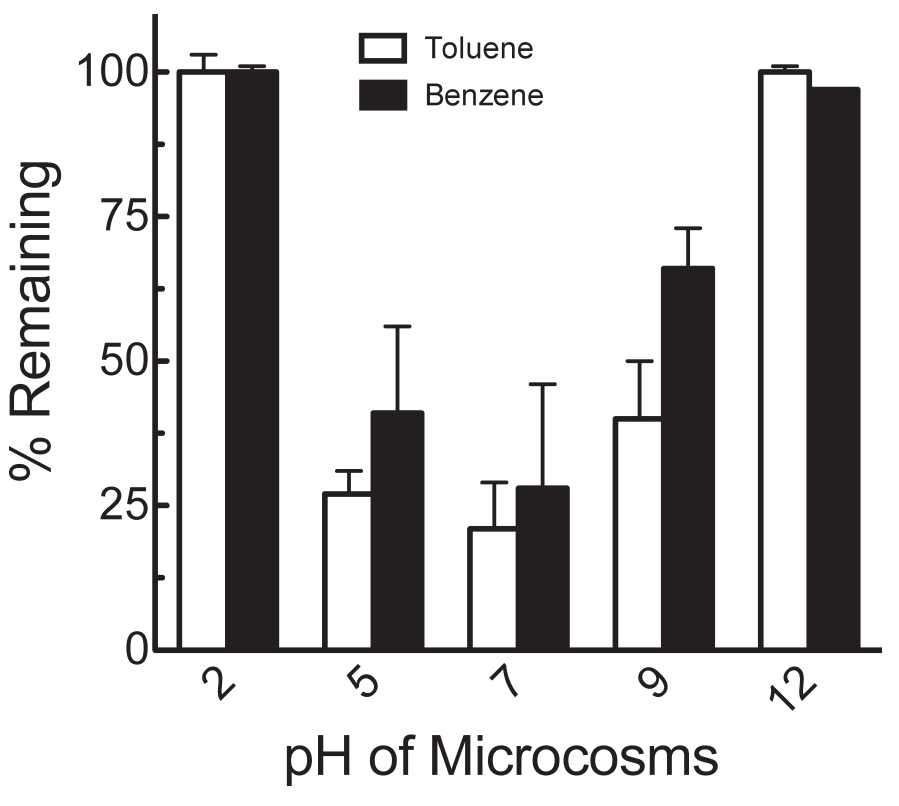

Figure 9. Aerobic biodegradation of benzene and toluene in microcosms with adjusted $\mathrm{pH}$ using raw water from well MW-3. The y-axis displays the percent benzene or toluene remaining in the microcosms after 5 days. No degradation of the organic compounds was observes at the extremes of $\mathrm{pH}$. Sterile controls lost less than $2 \%$ over the 5 days of incubation. Three replicates per treatment; error bars represent coefficient of variation.

collected from a clean part of the aquifer. However, the median difference in size was not statistically significant due to the wide range of sizes in both clean and fuelcontaminated parts of the aquifer.

Bacteria from the clean, aerobic section and the anaerobic, fuel-contaminated section of the aquifer were able to biodegrade benzene and toluene. The half-lives for aerobic benzene and toluene biodegradation at $25^{\circ} \mathrm{C}$ were 1.1 and 0.7 days, respectively. The aquifer in this study was a steady $14.7{ }^{\circ} \mathrm{C}$ over the course of this study. Assuming the Arrhenius principle applies to the biodegradation kinetics, which states that for every $10{ }^{\circ} \mathrm{C}$ increase there is an approximate doubling of the reaction rate (Laidler, 1984), the half-life of benzene and toluene in situ should be closer to 1.5 to 3 days. By comparison, under anaerobic conditions, the benzene and toluene had laboratory halflives of 23 to 26 days, which should be closer to 50 days in the natural anaerobic aquifer environment. The optimum $\mathrm{pH}$ observed in the laboratory microcosms under aerobic conditions was between 6 and 7. This $\mathrm{pH}$ range is reasonable, considering this aquifer system generally had a $\mathrm{pH}$ ranging from 6.4 to 7.8 , with the exception of well MW-1, which was influenced by development of a new well in close proximity. The $\mathrm{pH}$ in well $\mathrm{MW}-1$ was initially $\mathrm{pH}$ $\sim 7$ but increased to $\mathrm{pH} 12$. This study showed that there are large numbers of bacteria in the water-saturated karst conduits of south-central Kentucky that are adapted to their environment and fully capable of degrading light fuels.

\section{AcKNOWLEDGEMENTS}

The authors wish to thank Dr. L. King-Thomas, J. Cartwright, H. Welch, S. Cooper, and two anonymous journal reviewers for their constructive review comments and suggestions.

\section{REFERENCES}

Barton, H.A., Taylor, M.R., and Pace, N.R., 2004, Molecular phylogenetic analysis of a bacterial community in an oligotrophic cave environment: Geomicrobiology Journal, v. 21, p. 11-20. doi:10.1080/ 01490450490253428.

Barton, H.A., 2006, Introduction to cave microbiology: A review for the non-specialist: Journal of Cave and Karst Studies, v. 68, no. 2, p. $43-54$.

Barton, H.A., and Jurado, V., 2007, What's up down there? Microbial diversity in caves: Microbe, v. 2, no. 3, p. 132-138.

Barton, H.A., and Northup, D.E., 2007, Geomicrobiology in cave environments: past, current and future perspectives: Journal of Cave and Karst Studies, v. 69 , no. 1, p. 163-178.

Beveridge, T.J., 2001, Use of the Gram stain in microbiology: Biotechic \& Histochemistry, v. 76, no. 3, p. 111-118.

Byl, T.D., and Williams, S.D., 2000, Biodegradation of chorinated ethenes at a karst site in Middle Tennessee: U.S. Geological Survey WaterResources Investigations Report 99-4285, 58 p.

Byl, T.D., Hileman, G.E., Williams, S.D., and Farmer, J.J., 2001, Geochemical and microbial evidence of fuel biodegradation in a contaminated karst aquifer in southern Kentucky, June 1999, in Kuniansky, E.L., ed., U.S. Geological Survey Karst Interest Group Proceedings, St. Petersburg, Florida, February 13-16, 2001: U.S. Geological Survey Water-Resources Investigations Report 01-4011, p. $151-156$.

Byl, T.D., Hileman, G.E., Williams, S.D., Metge, D.W., and Harvey, R.W., 2002, Microbial strategies for degradation of organic contaminants in karst, in Aikens, G.R., and Kuniansky, E.L., eds., U.S. Geological Survey Artificial Recharge Workshop Proceedings, Sacramento, California, April 2-4, 2002: U.S. Geological Survery OpenFile Report 02-89, p. 61-62.

Cullimore, D.R., 2008, Practical Manual of Groundwater Microbiology, second edition: Boca Raton, Florida, Taylor and Francis Group, 376 p.

Dames and Moore, Inc., 2001, Remedial Investigations Report, Fort Campbell, Kentucky: prepared for U.S. Army Toxic and Hazardous Materials Agency, Aberdeen Proving Ground, Maryland, contract number 15-88-D-0008, 2 volumes.

DBI, 2003, BART User Manual, 2004 edition, Droycon Bioconcepts Inc, Regina, Saskatchewan, 54 p., http://www.dbi.ca/BARTs/Docs/Manual. pdf [accessed March 1, 2013]

Ewers, R.O., Duda, A.J., Estes, E.K., Idstein, P.J., and Johnson, K.M., 1992, The transmission of light hydrocarbon contaminants in limestone karst aquifers, in Proceeding of the Third Conference on Hydrogeology, Ecology, Monitoring, and Management of Ground Water in Karst Terranes: Dublin, Ohio, Water Well Journal Publishing, p. 287-306.

Fahy, A., Ball, A.S., Lethbridge, G., McGenity, T.J., and Timmis, K.N., 2008, High benzene concentrations can favour Gram-positive bacteria in groundwaters from a contaminated aquifer: FEMS Microbiolial Ecology, v. 65, p. 526-533. doi:10.1111/j.1574-6941.2008.00518.x.

Florea, L.J., Paylor, R.L., Simpson, L., and Gulley, J., 2002, Karst GIS advances in Kentucky: Journal of Cave and Karst Studies, v. 64, no. 1 , p. $58-62$.

Ford, R.M., and Harvey, R.W., 2007, Role of chemotaxis in the transport of bacteria through saturated porous media: Advances in Water Resources, v. 30, p. 1608-1617. doi:10.1016/j.advwatres.2006.05.019.

Grossart, H.-P., Steward, G.F., Martinez, J., and Azam, F., 2000, A simple, rapid method for demonstrating bacterial flagella: Applied 
and Environmental Microbiology, v. 66, p. 3632-3636. doi:10.1128/ AEM.66.8.3632-3636.2000.

Haack, S.K., Metge, D.W., Fogarty, L.R., Meyer, M.T., Barber, L.B., Harvey, R.W., LeBlanc, D.R., and Kolpin, D.W., 2012, Effects on groundwater microbial communities of an engineered 30-day in-situ exposure to the antibiotic sulfamethoxazole: Environmental Science and Technology, v. 46, no. 14, p. 7478-7486. doi:10.1021/ es3009776.

Harschey, R.M., 2003, Bacterial motility on a surface: many ways to a common goal: Annual Review of Microbiology, v. 57, p. 249-273. doi:10.1146/annurev.micro.57.030502.091014.

Harvey, R.W., Smith, R.L., and George, L., 1984, Effect of organic contamination upon microbial distributions and heterotrophic uptake in a Cape Cod, Mass., aquifer: Applied and Environmental Microbiology, v. 48, p. 1197-1202.

Harvey, R.W., Metge, D.W., Kinner, N., and Mayberry, N., 1997, Physiological considerations in applying laboratory-determined buoyant densities to predictions of bacterial and protozoan transport in groundwater: Results of in-situ and laboratory tests: Environmental Science and Technology, v. 31, p. 289-295. doi:10.1021/es960461d.

Harvey, R.W., Metge, D.W., Barber, L.B., and Aiken, G.R., 2010, Effects of altered groundwater chemistry upon the $\mathrm{pH}$-dependency and magnitude of bacterial attachment during transport within an organically contaminated sandy aquifer: Water Research, v. 44, p. 1062-1071. doi:10.1016/j.watres.2009.09.008

Harvey, R.W., Metge, D.W., Mohanram, A., Gao, Xiaodong, and Chorover, J., 2011, Differential effects of dissolved organic carbon upon re-entrainment and surface properties of groundwater bacteria and bacteria-sized microspheres during transport through a contaminated, sandy aquifer: Environmental Science and Technology, v. 45, p. 3252-3259. doi:10.1021/es102989x.

Hutson, S.S., 1995, Ground-water Use by Public-Supply Systems in Tennessee in 1990: U.S. Geological Survey Open-File Report 94-483, 1 sheet.

Kölbel-Boelke, J., Anders, E.-M., and Nehrkorn, A., 1988, Microbial communities in the saturated groundwater environment, II. Diversity of bacterial communities in a Pleistocene sand aquifer and their in vitro activities: Microbial Ecology, v. 16, p. 31-48. doi:10.1007/BF02097403.

Laidler, K., 1984, The development of the Arrhenius equation: Journal of Chemical Education, v. 61, p. 494-498. doi:10.1021/ed061p494.
McBride, M.J., 2001, Bacterial gliding motility: multiple mechanisms for cell movement over surfaces: Annual Review of Microbiology, v. 55, p. 49-75. doi:10.1146/annurev.micro.55.1.49.

Northup, D.E., and Lavoie, K.H., 2001, Geomicrobiology of caves: a review: Geomicrobiology Journal, v. 18, p. 199-222. doi:10.1080/ 01490450152467750 .

Quinlan, J.F., 1989, Ground-water monitoring in karst terranes: recommended protocols and implicit assumptions: Las Vegas, Nevada, U.S. Environmental Protection Agency, Environmental Monitoring Systems Laboratory, EPA/600/X-89/050, 88 p.

Ramos, J.L., Duque, E., Gallegos, M.-T., Godoy, P., Ramos-González, M.I., Rojas, A., Terán, W., and Segura, A., 2002, Mechanisms of solvent tolerance in Gram-negative bacteria: Annual Review of Microbiology, v. 56, p. 743-768. doi:10.1146/annurev.micro.56.012302.161038.

Ryan, M., and Meimen, J., 1996, An examination of short-term variations in water quality at a karst spring in Kentucky: Ground Water, v. 34, no. 1, p. 23-30. doi:10.1111/j.1745-6584.1996.tb01861.x.

Schneider, K., and Culver, D.C., 2004, Estimating subterranean species richness using intensive sampling and rarefaction curves in a high density cave region in West Virginia: Journal of Cave and Karst Studies, v. 66, p. 39-45.

Segura, A., Duque, E., Mosqueda, G., Ramos, J.L., and Junker, F., 1999, Multiple responses of Gram-negative bacteria to organic solvents: Environmental Microbiology, v. 1, no. 3, p. 191-198. doi:10.1046/ j.1462-2920.1999.00033.x.

Vesper, D.J., and White, W.B., 2006, Comparative storm response of contaminants in a carbonate aquifer, Fort Campbell, KentuckyTennessee, in Harmon, R.S., and Wicks, C., eds., Perspectives on Karst Geomorphology, Hydrology, and Geochemistry-A Tribute Volume to Derek C. Ford and William B. White: Geological Society of America Special Paper 404, p. 267-274. doi:10.1130/ 2006.2404(22).

White, W.B., 2002, Karst hydrology; recent developments and open questions: Engineering Geology, v. 65, p. 85-105. doi:10.1016/S00137952(01)00116-8.

Wolfe, W.J., Haugh, C.J., Webbers, A., and Diehl, T.H., 1997, Preliminary conceptual models of the occurrence, fate, and transport of chlorinated solvents in karst aquifers of Tennessee: U.S. Geological Survey Water-Resources Investigations Report 97-4097, 80 p. 